\title{
Eksplorasi Mikroba Penghasil Enzim-enzim Hidrolitik Di Kawasan Taman Nasional Lore Lindu Sulawesi Tengah
}

\author{
Rahmiati, Sri Pujianto dan Endang Kusdiyantin \\ Laboratorium Bioteknologi, Departemen Biologi, \\ Fakultas Sains dan Matematika, Universitas Diponegoro, Semarang \\ Jln Prof. Soedarto, SH,Semarang,50275, Telp: (024)7474754; Fax (024) 76480923 \\ Email : mhyarahmiati@gmail.com
}

\begin{abstract}
Lore Lindu National Park (TNLL) is an area that flora, fauna and microbes, the diversity of microbes producing hydrolytic enzyme. explore the hydrolytic enzyme producing microbes in Indonesia. This study was aimed to obtain bacterial isolates were able to produce hydrolytic enzyme and characteristics. Isolation in the microbiology laboratory. Isolation by a spread plate. Isolates in the selection hydrolytic enzyme producing selective media. Measurement of the activity of the enzyme with hydrolytic index. The results were thirteen isolates clearing zone test, 2 protease enzyme bacterial isolates, 1 lipase enzyme bacterial isolates, 6 amylase enzyme bacterial isolates, while 4 cellulase enzyme bacterial isolates. Examination of Amylase enzyme activity was done using DNS method. L10T3 showed that the bacterial isolate optimum activity at $\mathrm{pH} 7$ and at a temperature of $30^{\circ} \mathrm{C}$ with an activity of $0.040 \mathrm{U} / \mathrm{mL}$ and $0.029 \mathrm{U} / \mathrm{mL}$.
\end{abstract}

Key word: Lore Lindu National Park, hydrolytic enzyme. isolation of bacteria

\begin{abstract}
Abstrak
Taman Nasional Lore Lindu (TNLL) merupakan kawasan yang memiliki kekayaan flora, fauna dan mikroba, sehingga memungkinkan terdapat keanekaragaman mikroba penghasil enzim hidrolitik. Pencarian sumber penghasil enzim hirolitik perlu dilakukan dari mikroba di Indonesia. Penelitian ini bertujuan untuk mendapatkan isolat bakteri yang mampu menghasilkan enzim hidrolitik serta karakteristiknya. Isolasi di laboratorium mikrobiologi. Isolasi dilakukan dengan cara spread plate. Isolat murni di seleksi kemampuan penghasil enzim hidrolitik pada media selektif. Pengukuran aktivitas enzim dengan perhitungan indeks hidrolitiknya. Hasil menunjukkan ada tiga belas isolat di uji zona bening, 2 isolat bakteri menghasilkan enzim protease, 1 isolat bakteri menghasilkan enzim lipase, 6 isolat bakteri menghasilkan enzim amilase sedangkan 4 isolat menghasilkan enzim selulase. Uji aktivitas enzim amilase menggunakan metode DNS, menunjukkan bahwa isolat bakteri L10T3 memiliki aktivitas optimum pada $\mathrm{pH} 7$, dan pada suhu $30^{\circ} \mathrm{C}$ dengan aktivitas sebesar $0.040 \mathrm{U} / \mathrm{mL}$ dan 0.029 $\mathrm{U} / \mathrm{mL}$.
\end{abstract}

Kata kunci: Taman Nasional Lore Lindu, enzim hidrolitik, isolasi bakteri

\section{PENDAHULUAN}

Indonesia memiliki keanekaragaman hayati terdiri dari berbagai jenis tumbuhan, hewan dan mikroba memiliki potensi dalam produksi enzim. Enzim dihasilkan oleh semua makhluk hidup untuk mengkatalisis reaksi biokimia dalam tubuh makhluk hidup tersebut sehingga reaksi-reaksi itu dapat berlangsung lebih cepat (Sianturi, 2008). Enzim yang bersumber dari mikroorganisme secara umum banyak diminati oleh industri sebab memiliki beberapa keuntungan dibandingkan dari sumber lain seperti hewan dan tumbuhan. Dewasa ini enzim sudah banyak dimanfaatkan untuk berbagai keperluan komersial didalam industri, produk pertanian, kimia dan medis karena efesien kerja yang tinggi dapat dihasilkan dari berbagai sumber dengan biaya yang lebih rendah. Enzim merupakan salah satu produk alami yang memegang peranan penting dalam berbagai aplikasi industri, mulai dari proses pengolahan makanan sampai produk bahan kimia berharga. 
Sebenarnya enzim bukan hal yang baru dikalangan masyarakat karena secara tradisional telah digunakan sejak dahulu kala, seperti dalam pembuatan keju, penyamakan kulit dan pelunakan daging (Oost \& Graaf 2003).

Sifat-sifat tersebut menyebabkan penggunaan enzim semakin meningkat dari tahun ketahun, peningkatan diperkirakan mencapai 10$15 \%$ per tahun (Rahayu, et al., 2004). Salah satu kelompok enzim yang memiliki manfaat yang sangat penting dalam bidang industri adalah hidrolitik.

Produksi dan perdagangan enzim didominasi oleh kelompok enzim hidrolitik seperti amilase, protease, selulase, katalase dan lipase. Banyak penelitian yang dilakukan baik di Indonesia maupun di luar Indonesia untuk mencari dan mendapatkan informasi tentang penghasil enzim hidrolitik ini. misalnya Ardakani, et al., (2010) berhasil mengisolasi halophilik Pseudoalteromonas yang memproduksi enzim hidrolitik dari Teluk Persia. Selain itu Davit et al., (2012) berhasil mengisolasi bakteri termofilik yang menghasilkan enzim hidrolitik dari pupuk kompos, dimana ditemukan sepuluh bakteri termofilik dengan suhu optimum $\left(60-65^{\circ} \mathrm{C}\right)$ yang diisolasi dari kotoran kompos.

Protease tahan panas, $\alpha$-amilase, dan xilanase juga diamati dan thermodenitrificans. Hongyue et al., (2008), berhasil mengisolasi enzim hidrolitik pada bakteri heterotrofik dari sedimen laut dari Okinawa, ditemukan 98 bakteri heterotrophik. Dirnawan, et al., (2000) berhasil mengisolasi 18 bakteri termofil aerob dengan kondisi kultivasi $700 \mathrm{C}$ dan $\mathrm{pH}$ 7.5. Isolat-isolat tersebut terdeteksi mempunyai aktivasi enzim hidrolitik ekstraseluler, yaitu proteolitik, amilolitik, lipolitik, kitinolitik, dan xilanolitik dari sumber air panas gunung panjar.

Taman Nasional Lore Lindu (TNLL) merupakan kawasan yang unik. Kawasan ini dapat disebut sebagai jantung Sulawesi karena terletak pada pertemuan tiga lempeng Sulawesi. Di kawasan seluas 217.991,18 ha, taman nasional ini memiliki kekayaan flora khas Sulawesi (Suprianto, 2012). Kondisi keanekaragaman hayati tersebut sangat sebagai sumber penghasil enzim. Di Daerah Palu Sulawesi Tengah memiliki informasi tentang potensi mikroba penghasil enzim hidrolitik yang masih kurang, dengan demikian dalam penelitian ini akan dilakukan dalam penelitian ini akan dilakukan eksplorasi mikroba penghasil enzim hidrolitik yang bersumber dari kawasan Taman Nasional Lore Lindu memungkinkan terdapatnya keanekaragaman mikroba penghasil enzim hidrolitik. Penelitian tentang mikroba penghasil enzim hidrolitik penting untuk dilakukan sebagai alternatif baru.

\section{BAHAN DAN METODE}

Penelitian ini dilaksanakan pada bulan Oktober 2014 sampai Mei 2015 di Laboratorium Mikrobiologi Jurusan Biologi Fakultas Sains dan Matematika, dan Laboratorium Terpadu, Universitas Diponegoro, Semarang.

Alat dan bahan yang digunakan dalam penelitian ini meliputi tabung reaksi, gelas ukur erlenmeyer, cawan petri, gelas piala, tabung reaksi, pipet tetes, magnetik stirer, hotplate, jarum ose, autoklaf, spektrofotometer, mikro pipet, lampu spiritus, timbangan analitik dan inkubator. sampel tanah yang berasal dari Taman Nasional Lore Lindu Medium Nutrien Agar (NA), CMC, minyak zaitun, pepton, susu skim, alkohol, iodin, aquades, alumanium foil, kapas, kain kasa, tissue.

Pengambilan sampel tanah dilakukan di Taman Nasional Lore Lindu Palu. Tanah Penghasilnya : tanah 1 ( di pinggir danau Lindu), tanah 2 (di pinggiran rumah warga yang mengandung minyak), tanah 3 (berlokasi dekat umbi-umbian sekitar rumah warga), sedangkan tanah 4 (tanah yang mengandung banyak serasah).

\section{Isolasi mikroba penghasil enzim}

Penghasil enzim protease: Isolasi mikroba dilakukan dengan mengambil $0.5 \mathrm{~g}$ sampel tanah yang disebarkan pada media Skim Milk Agar (SMA) pH7 yang mengandung $1 \mathrm{~g}$ susu skim. Inkubasi dilakukan pada suhu $35^{\circ} \mathrm{C}$ selama 2 hari dan diamati adanya koloni mikroba yang memiliki zona bening. Seleksi dilakukan secara semikuantitatif dengan membandingkan nilai indeks proteolitik (IP) berbagai isolat.

Penghasil enzim amylase : Isolasi mikroba penghasil enzim amilase dilakukan dengan mengambil sampel $0.5 \mathrm{~g}$ tanah, selanjutnya menumbuhkan isolat pada media NA yang 
ditambah pati 2 g. Inkubasi dilakukan pada suhu $35^{\circ} \mathrm{C}$ selama 2 hari. Selanjutnya dilakukan pewarnaan dengan iodin dan koloni yang bersifat positif dapat diketahui dengan melihat areal bening (kuning) yang muncul di sekelilingnya. Indeks amilolitik (IA) dapat diukur dengan membandingkan diameter zona bening dengan diameter koloni.

Penghasil enzim lipase : Sebanyak $0.5 \mathrm{~g}$ tanah, diinokulasi kedalam $100 \mathrm{ml}$ medium NA sebagai stater dan dinkubasi selama 2 hari, selanjutnya dimasukkan minyak zaitun $1 \mathrm{ml}$ dan diinkubasi pada suhu $35^{\circ} \mathrm{C}$ selama 2 hari. indeks lipolitik dapat diukur dengan membandingkan diameter zona bening dengan diameter koloni.

Produksi enzim selulase : Sebanyak $0.5 \mathrm{~g}$ tanah selanjutnya diinokulasi kedalam $100 \mathrm{ml}$ media NA dan ditambahkan carboxy methyl celullose (CMC) $1 \mathrm{~g}$ (Lampiran 1) inkubasi pada suhu $35^{\circ} \mathrm{C}$ selama 2 hari. Indeks Selulolitik (IS) dapat diukur dengan membandingkan diameter zona bening dengan diameter koloni.

Pengukuran aktivitas enzim amilase : Aktivitas enzim amilase dideterminasi lewat metode DNS dengan menggunakan pati sebagai substrat, supernatan dari kultur enzim amilase kasar digunakan sebagai sampel enzim. Aktivitas enzim amilase dihitung berdasarkan data kadar glukosa relatif sebagai mg glukosa yang dihasilkan oleh $1 \mathrm{ml}$ kasar amilase. Satu Unit aktivitas enzim didefenisikan sebagai banyaknya $\mu \mathrm{mol} / \mathrm{ml}$ glukosa yang dihasilkan dari hidrolisa pati oleh $1 \mathrm{ml}$ ekstrak kasar enzim amilase selama masa inkubasi.

Karakteristik enzim amylase : Ekstrak kasar enzim diperoleh dengan sentrifugasi kultur sel pada 6000 rpm selama 20 menit. Supernatan yang mengandung enzim amilase kasar diambil dengan mikropipet dengan uji aktivitas suhu terhapap enzim amilase yaitu enzim kasar dicampurkan sebanya $1 \mathrm{ml}$ kedalam tabung uji, lalu ditambahkan $1 \mathrm{ml}$ larutan pati tapioka yang dilarutkan kedalam sitrat buffer fosfat pada $\mathrm{pH} 7$. Campuran tersebut diinkubasi pada water bath selama 20 menit, pada suhu $30^{\circ} \mathrm{C}, 35^{\circ} \mathrm{C}, 40^{\circ} \mathrm{C}$, $45^{\circ} \mathrm{C}, 50^{\circ} \mathrm{C}, 55^{\circ} \mathrm{C}$, dan $60^{\circ} \mathrm{C}$ sedangkan $\mathrm{pH} \mathrm{pH} 4$, $\mathrm{pH} 5, \mathrm{pH} 6, \mathrm{pH} 7, \mathrm{pH} 8$ dan $\mathrm{pH}$. Penambahan $2 \mathrm{ml}$ DNS untuk menghentikan reaksi, dipanaskan selama 5 menit kemudian didinginkan selama 15 menit pada air mengalir untuk menginaktivasi enzim tersebut. Pengujian dengan spectrometer pada panjang gelombang $540 \mathrm{~mm}$.

\section{HASIL DAN PEMBAHASAN}

Isolat bakteri tersebut diuji kemampuannya menghasilkan enzim hidrolitik dengan menggunakan media selektif protease, lipase, amilase dan selulase. Hasil menunjukkan bahwa 13 isolat menghasilkan enzim hidrolitik. Ketiga belas isolat bakteri tersebut adalah : 2 isolat berasal dari tanah 1 ( di pinggir danau Lindu), 1 isolat dari tanah 2 (di pinggiran rumah warga yang mengandung minyak), 6 isolat dari tanah 3 (berlokasi dekat umbi-umbian sekitar rumah warga), sedangkan 4 isolat dari tanah 4 (tanah yang mengandung banyak serasah). Bakteri penghasil enzim hidrolitik di tunjukkan pada Tabel 1. 
Tabel 1: Indeks hidrolitik penghasil enzim hidrolitik di kawasan Taman Nasional Lore Lindu

\begin{tabular}{cccccc}
\hline & & \multicolumn{4}{c}{ Enzim Hidrolitik } \\
\cline { 3 - 6 } No & Isolat & Proteolitik & Lipolitik & Amilolitik & Selulolitik \\
\hline 1 & L6T1 & 0.20 & - & - & - \\
2 & L9T1 & 0.54 & - & - & - \\
3 & L6T2 & - & 0.47 & - & - \\
4 & L3T3 & - & - & 0.6 & - \\
5 & L6T3 & - & - & 0.4 & - \\
6 & L7T3 & - & - & 0.82 & - \\
7 & L8T3 & - & - & 0.33 & - \\
8 & L9T3 & - & - & 0.73 & - \\
9 & L10T3 & - & - & 0.84 & - \\
10 & L2T4 & - & - & - & 0.45 \\
11 & L4T4 & - & - & - & 0.33 \\
12 & L6T4 & - & - & - & 0.39 \\
13 & L9T4 & - & - & - & 0.22 \\
& & & & & \\
\hline
\end{tabular}

Keterangan: (-) Tidak menghasilkan enzim hidrolitik

Aktivitas Amilase Isolat Bakteri L10T3 Pada Suhu yang Berbeda

Pengujian aktivitas enzim amilase yang diperoleh dari isolat L10T3 yang menghidrolisis pati menunjukkan kemampuan aktivitas enzim amilase terhadap suhu, menunjukkan bahwa suhu optimum untuk bakteri tanah di kawasan Tama Nasional Lore Lindu yaitu suhu optimum $30^{\circ} \mathrm{C}$. Di dukung hasil penelitian sebelumnya oleh Raharjo et al.(2008) pada tanah Taman Nasional Rawa Aopa Watumaohai, memiliki suhu optimum $45^{\circ} \mathrm{C}$. Ketika iso isolat $\mathrm{L} 10 \mathrm{~T} 3$ dinaikan padasuhu $55^{\circ} \mathrm{C}$ mengalami penurunan, dimana terjadinya penurunan yang drastis yang disebabkan karena rusaknya atau matinya bakteri tersebut sehingga tidak bisa menghasilkan enzim amilase. Pengaruh suhu terhadap aktivitas enzim ditunjukan pada Tabel 2.

Tabel 2. Aktivitas Amilase Isolat Bakteri L10T3 Pada Suhu yang Berbeda

\begin{tabular}{llll}
\hline No & $\begin{array}{l}\text { Suhu } \\
\left({ }^{0} \mathrm{C}\right)\end{array}$ & $\begin{array}{l}\text { Konsentrasi } \\
\text { Glukosa }(\mathrm{mg} / \mathrm{mL})\end{array}$ & $\begin{array}{l}\text { Aktivitas Enzim } \\
\text { Unit/mL }\end{array}$ \\
\hline 1 & 30 & 1.0253 & $0.029^{\mathrm{a}}$ \\
2 & 35 & 1.0539 & $0.028^{\mathrm{a}}$ \\
3 & 40 & 0.9860 & $0.027^{\mathrm{b}}$ \\
4 & 45 & 0.8681 & $0.024^{\mathrm{c}}$ \\
5 & 50 & 0.5037 & $0.022^{\mathrm{d}}$ \\
6 & 55 & 0.7717 & $0.013^{\mathrm{e}}$ \\
7 & 60 & 0.2358 & $0.007^{\mathrm{f}}$ \\
\hline
\end{tabular}

Keterangan: Huruf yang berbeda pada notasi dari masing-masing isolat menunjukkan pengaruh yang berbeda nyata pada tingkat kepercayaan $95 \%$. 


\section{Aktivitas Amilase Isolat Bakteri L10T3 Pada pH yang Berbeda}

Hasil pengujian ke empat enzim hidrolitik di kawasan Taman Nasional Lore Lindu, dimana zona bening terpilih yaitu isolat bakteri L10T3 nilai indeks amilase 0.84. Penentuan $\mathrm{pH}$ optimum dari enzim amilase dilakukan sesuai dengan prosedur aktivitas enzim amilase dengan menginkubasi enzim menggunakan substrat pati $1 \mathrm{ml}$ dan suhu optimum $30^{\circ} \mathrm{C}$ dengan $\mathrm{pH}$ yaitu $\mathrm{pH} 4,5,6$, dan 7. Pengaruh $\mathrm{pH}$ pada aktivitas enzim terlihat dari perbedaan nilai yang didapat saat pengujian dengan menggunakan $\mathrm{pH}$ yang berbeda diperoleh hasil konsentrasi glukosa hasil hidrolisis pati seperti terlihat pada Tabel 3 .

Tabel 3. Aktivitas Amilase Isolat Bakteri L10T3 Pada pH yang Berbeda

\begin{tabular}{cccl}
\hline No & pH & $\begin{array}{c}\text { Konsentrasi } \\
\text { Glukosa }(\mathbf{m g} / \mathbf{m L})\end{array}$ & $\begin{array}{c}\text { Aktivitas Enzim } \\
\text { Unit/mL }\end{array}$ \\
\hline 1 & 4 & 1.1254 & $0.031^{\mathrm{e}}$ \\
2 & 5 & 1.2504 & $0.034^{\mathrm{d}}$ \\
3 & 6 & 1.3647 & $0.038^{\mathrm{b}}$ \\
4 & 7 & 1.4433 & $0.040^{\mathrm{a}}$ \\
5 & 8 & 1.3076 & $0.036^{\mathrm{c}}$ \\
6 & 9 & 1.1111 & $0.031^{\mathrm{e}}$ \\
\hline
\end{tabular}

Ket: Huruf yang berbeda pada notasi dari masing-masing isolat menunjukkan pengaruh yang berbeda nyata pada tingkat kepercayaan $95 \%$.

Hasil karakterisasi terhadap $\mathrm{pH}$ menunjukkan bahwa enzim amilase yang dihasilkan oleh isolat L10T3 tertinggi pada $\mathrm{pH}$ 7. Hal ini menunjukkan enzim amilase dari isolat L10T3 lebih cocok digunakan pada $\mathrm{pH}$ yang netral untuk mendapatkan hasil yang optimum. Hal ini sama dengan penelitian Dali, et al., (2013) menyatakan bahwa enzim amilase dari isolat bakteri termofilik Bacillus Substilis memiliki pH optimum 7. Sianturi (2008) menyatakan bahwa aktivitas enzim amilase dari isolat PN4 terus meningkat dari $\mathrm{pH} 4-6$, dan isolat PN9 yang aktivitas enzimnya juga meningkat dari $\mathrm{pH}$ 4-7.

Enzim pada umumnya memiliki $\mathrm{pH}$ optimum 7 atau sekitarnya sehingga kerja enzim optimum, karena suasana yang terlalu asam atau alkalis menyebabkan denaturasi protein dan hilangnya secara total aktivitas enzim. Ketika $\mathrm{pH}$ media produksi semakin dinaikkan yaitu $\mathrm{pH} 8$ dan $\mathrm{pH} 9$ terlihat adanya penurunan jumlah aktivitas enzim amilase yang dihasilkan. Hal ini sama ketika $\mathrm{pH}$ media produksi berada di bawah $\mathrm{pH} 7$, yaitu $\mathrm{pH} 5$ dan $\mathrm{pH} 6$ dimana terjadinya penurunan hasil. Enzim pada umumnya memiliki $\mathrm{pH}$ optimum 7 atau sekitarnya sehingga kerja enzim optimum, karena suasana yang terlalu asam atau alkalis menyebabkan denaturasi protein dan hilangnya secara total aktivitas enzim

\section{KESIMPULAN}

Berdasarkan penelitian dapat diambil kesimpulan sebagai berikut:

1. Taman Nasional Lore lindu memiliki isolat bakteri yang berbeda-beda karakter morfologi dan sebanyak 13 isolat bakteri tersebut menghasilkankan enzim hidrolitik.

2. Ketiga belas isolat bakteri tersebut adalah :2 isolat berasal dari tanah 1( Bakteri penghasil enzim protease), 1 isolat dari tanah 2 (Bakteri penghasil lenzim lipase ), 6 isolat dari tanah 3 (Bakteri penghasil enzim amilase), sedangkan 
4 isolat dari tanah 4 (Bakteri penghasil enzim selulase).

3. Enzim Amilase yang dihasilkan dari isolat bakteri L10T3 memiliki pH 7 dan suhu $30^{\circ} \mathrm{C}$ dengan aktivitas sebesar $0.040 \mathrm{U} / \mathrm{mL}$ dan $0.029 \mathrm{U} / \mathrm{mL}$ ).

\section{DAFTAR PUSTAKA}

Ardakani. M.R. Poshtkouhian A., Amoozegar M. A., Zolgharnein H. 2010 Isolation of moderately halophilic pseudoalteromonas producing extracellular hydrolytic enzymes from Persian Gulf. Indian. J. Microbial 52(1):94-98.

Dali S., Rugaiyah A., Karim A. Rauf P. A. 2013. Karakteristik enzim amilase dari isolat bakteri termofilik Bacillus Substilis. Fakultas MIPA. Universitas Hasanudin. Makassar.

David M. Charbonneaub. Fatma M. M. Maurice Boissinot. Marc Sirois. Marc .Beauregard2012. Identification of thermophilic bacterial strains producing thermotolerant hydrolytic enzymes from manure compost. Indian J. Microbial. 52(1):41-47.

Hongyue D., Hu Z., Jing W., Tiegang L. 2009. Extracellular hydrolytic enzyme screening of culturable heterotrophic bacteria from deep-sea sediments of the Southern Okinawa Trough. J Microbiol Biotech 25:71-79.

Oost Van Der. J \& Graff De. L. 2003. Applied Moleculer Genetics. A teaching module. Wagening University.

Raharjo S., Ardiansyah. Chahyadi A. 2008. Isolasi dan karakteristik $\alpha$-amilase isolat bakteri amilolitik asidofilik dari Taman Nasional Rawa Aopa Watumohai. J. Indones Chimica Acta. 1(1):15-23.

Rahayu, S., Tanuwidjaya, F., Rukayadi, Y., Suwanto, A.,Suhartono, M. T., Hwang, J. K, \& Pyun, Y.R. 2004. Study of Thermostable Chitinase Enzymes from Indonesian Bacillus K29-14. J. Microbiol. Biotechnol. 14(4): 647-652.

Sianturi. D.C., 2008. Isolasi bakteri dan uji aktivitas amilase termofil kasar dari sumber air panas penen Sibiru Sumatera Utara. Tesis diterbitkan. Sekolah Pascasarjana Universitas Sumatera Utara. Medan.

Suprianto T. 2012. Menjaga Kelestarian dan Memulihkan Taman Nasional Lore Lindu. Balai Taman Nasional Lore Lindu. Palu. Sulawesi Tengah. 